Didaktik : Jurnal Pendidikan, ISSN : 2477-5673, E-ISSN : 2614-722X

Sekolah Tinggi Keguruan dan IImu Pendidikan Subang

Volume V Nomor 1, Juni 2019

\title{
PENGEMBANGAN BAHAN AJAR IPA TERPADU PADA TEMA KELISTRIKAN PADA MAKHLUK HIDUP DENGAN MENGGUNAKAN METODE FOUR STEP TEACHING MATERIAL DEVELOPMENT (4STMD)
}

\author{
Deti Lotaningrat \\ Sekolah Pascasarjana Universitas Pendidikan Indonesia \\ deti.lotaningrat@student.upi.edu
}

\begin{abstract}
This study aims to develop integrated science teaching materials on the theme "Electricity in Living Creatures" by using the Four Step Teaching Material Development Method (4STMD) which includes the Selection, Structuring, Categorization and Reduction of Dactic stages. This research uses Research and Development ( $R \& D$ ) methods. The subject of this study is all science teaching materials on the theme of electricity in living things studied using the 4STMD method. The data in this study were captured by using various types of instruments that were rationally validated (logical) and empirical (empirical) by experts at each stage of development. Data from expert validation were analyzed using CVR and CVI and percentage analysis. The opinions of students regarding the instructional materials developed and the feasibility of the developed teaching materials were collected using questionnaires. As a development evaluation material in the development of teaching materials, the effectiveness of instructional materials on the thinking ability of knowledge integration in students is also tested. As a comparison, also tested the effectiveness of other teaching materials. The effectiveness test results show that students who use teaching materials developed using the 4STMD method have a higher score (65) compared to students who use other teaching materials (60).
\end{abstract}

Keywords: Development of Instructional Materials, Integrated Science Process Material Development (4STMD) Four Steps

\begin{abstract}
ABSTRAK
Penelitian ini bertujuan untuk mengembangkan bahan ajar IPA terpadu pada tema "Kelistrikan pada Makhluk Hidup" dengan menggunakan metode Four Step Teaching Material Development (4STMD) yang meliputi tahap Seleksi, Strukturisasi, Kategorisasi dan Reduksi Didaktis. Penelitian ini menggunakan metode Riset dan Pengembangan (R\&D). Subjek penelitian ini merupakan seluruh bahan ajar IPA tema kelistrikan pada makhluk hidup yang dikaji
\end{abstract}


dengan menggunakan metode 4STMD. Data dalam penelitian ini dijaring dengan menggunakan berbagai jenis instrumen yang divalidasi secara rasional (logical) serta empirik (empirical) oleh ahli dalam setiap tahapan pengembangan. Data hasil validasi ahli dianalisis dengan menggunakan CVR dan CVI dan analisis persentase. Adapun pendapat siswa mengenai bahan ajar yang dikembangkan dan kelayakan bahan ajar yang dikembangkan dijaring dengan menggunakan kuisioner (angket). Sebagai bahan evaluasi pengembangan dalam pengembangan bahan ajar ini juga dilakukan uji keefektifitasan bahan ajar terhadap kemampuan berpikir integrasi pengetahuan pada siswa. Sebagai pembanding juga dilakukan uji keefektitifitasan bahan ajar lain. Hasil uji keefektifitasan menunjukkan bahwa siswa yang menggunakan bahan ajar yang dikembangkan dengan menggunakan metode 4STMD memiliki skor nilai lebih tinggi (65) dibandingkan dengan siswa yang menggunakan bahan ajar lain (60).

Kata Kunci: Pengembahan Bahan Ajar, Four step Teaching Material Development (4STMD) IPA Terpadu

\section{A. Pendahuluan}

Belajar merupakan suatu bagian dari proses pendidikan yang terus menerus dilakukan oleh manusia sepanjang hayat. Proses belajar dan pembelajaran dalam sistem pendidikan merupakan proses yang cukup rumit sebab melibatkan banyak aspek di dalamnya. Proses belajar mengajar dalam pendidikan sedikitnya melibatkan tiga aspek utama yaitu pembelajar (siswa) sebagai bahan baku, pengajar (guru) sebagai perantara atau penyampai informasi, dan bahan ajar sebagai pokok materi atau informasi yang akan diberikan kepada siswa atau pembelajar (Anwar, 2014). Dari ketiga aspek tersebut bahan ajar merupakan salah satu aspek penting yang perlu diperhatikan oleh para pelaku pendidikan karena pada dasarnya dalam proses belajar merupakan proses pengolahan bahan ajar yang didapatkan oleh siswa, sebagaimana dikatakan oleh Sagala (2009) bahwa dalam implementasinya belajar merupakan kegiatan individu untuk memperolah pengetahuan, prilaku dan keterampilan dengan cara mengolah bahan ajar.

Bahan ajar merupakan salah satu instrumen input bersama 
dengan kurikulum, pengajar, media, dan evaluasi. Untuk keberhasilan dalam proses pembelajaran bahan ajar perlu dikemas sedemikian rupa disesuaikan dengan jenjang usia dan tingkat berpikir siswa sehingga siswa mampu memahami bahan ajar dengan baik. Piaget (1971, dalam Suparno, 2001) mengungkapkan bahwa tahap perkembangan individu serta perubahan usia sangat mempengaruhi kemampuan belajar indvidu, selain itu setiap jenjang usia memiliki tahap perkembangan kognitif yang khas pada individu tersebut. Berdasarkan hal ini maka seorang guru sebagai transformator yang menyampaikan informasi kepada siswa perlu menyiapkan bahan ajar atau sumber informasi yang baik dan mudah dipahami oleh siswa sesuai dengan tingkat kemampuan berpikir siswa.

Bahan ajar yang diberikan kepada siswa tidak lepas dari ketentuan kurikulum yang berlaku. Kurikulum 2013 yang saat ini digunakan dikembangkan atas teori "pendidikan berdasarkan standar" (standard-based education), dan teori kurikulum berbasis kompetensi (competencybased curriculum). Menggunakan kurikulum berbasis kompetensi sebagai landasan teoritis kurikulum ini dirancang untuk memberikan pengalaman belajar seluasluasnya bagi peserta didik dalam mengembangkan kemampuan untuk bersikap, berpengetahuan, berketerampilan, dan bertindak (Permendikbud, 2013). Berdasarkan landasan teoritis ini tentu saja menjadi sebuah tuntutan bagi guru untuk dapat mengembangkan bahan ajar agar pengalaman belajar siswa sesuai dengan yang diharapkan oleh tuntutan kurikulum dan kebutuhan siswa.

Adapun model kurikulum untuk setiap kurikuler atau mata pelajaran pada kurikulum 2013 mengacu kepada integrated curricullum yang memadukan berbagai disiplin ilmu dalam setiap mata pelajaran. Keterintegrasian dalam berbagai disiplin ilmu pada setiap mata pelajaran merupakan sebuah tantangan baru untuk para ahli pendidikan dan pengajaran 
untuk membuat sebuah bahan ajar yang terpadu. Kurikulum yang terintegrasi menurut Forgaty (1991) merupakan model kurikulum yang menggambarkan sebuah pendekatan lintas disipliner yang memadukan berbagai disiplin utama dengan menempatkan tujuan utama masing-masing didalamnya, dan menemukan kesamaan keterampilan, konsep dan sikap yang ada di dalamnya untuk diajarkan.

\section{Berdasarkan}

kurikulum

2013

tuntutan

pembelajaran IPA menjadi sebuah keharusan agar bahan ajar disajikan secara terpadu antara satu disiplin ilmu dengan disiplin ilmu yang lainnya. Dalam bahan ajar untuk pembelajaran sains atau IPA yang terdiri atas Biologi, Kimia, dan Fisika, seharusnya sudah tidak lagi terlihat sebagai masingmasing disiplin ilmu, akan tetapi harus dapat menjadi satu kesatuan disiplin ilmu yaitu IPA yang diajarkan secara utuh sehingga siswapun memahaminya sebagai satu kesatuan yaitu IPA.

Untuk membuat bahan ajar IPA yang baik dengan konsep yang terintegrasi memang membutuhkan usaha dan memerlukan waktu yang tidak sebentar. Masih sedikitnya teori tentang pengembangan bahan ajar juga menjadi kesulitan tersendiri untuk mengembangkan bahan ajar IPA. Menurut Anwar (2014), untuk menyusun sebuah bahan ajar yang baik dapat digunakan sedikitnya empat langkah pendekatan yang dikenal sebagai Four Step Teaching Material Develpment (4STMD) yaitu meliputi; seleksi, strukturisasi, karakterisasi, dan reduksi didaktis.

Tahap pertama yaitu tahap seleksi, merupakan proses pemilihan bahan ajar dari mulai pemilihan buku ajar atau bahan ajar, penentuan kosep materi hingga terkumpul draf kompilasi materi. Adapun sumber buku ajar yang digunakan dapat berupa buku teks atau buku ajar yang diterbitkan dalam negeri ataupun terbitan luar negeri. Dalam tahap seleksi dilakukan juga pengkajian terhadap Kompetensi Inti (KI) dan Kompetensi Dasar (KD) kemudian menentukan tema yang sesuai, dan membuat indikator 
ketercapaiannya. Hal yang berbeda dari buku teks yang banyak dikembangkan (khususnya buku teks luar negeri) dalam tahapan seleksi pada metode 4STMD dikembangkan aspek nilainilai yang terkandung dalam konsep-konsep materi. Selanjutnya pada tahap ini dilakukan validasi terhadap draf materi yang terkumpul yang dilakukan oleh ahli (Expert Judgment).

Tahap kedua dari metode ini yaitu strukturisasi, merupakan tahap dimana setelah draft materi divalidasi kemudian dibuatkan peta konsep dan struktur makro untuk pembelajaran pada konsep-konsep tersebut. Agar materi yang disajikan dalam bahan ajar lebih jelas pada tahap strukturisasi juga dilakukan multiple representasi. Multiple representasi ini adalah upaya dalam penyajian data dengan berbagai bentuk atau mode terhadap kompilasi materi yang sudah ada. Dalam hal ini representasi yang digunakan meliputi representasi makroskopik, submikroskopik dan simbolik.

Tahap ketiga yaitu tahap karakterisasi. Pada tahap ini dilakukan uji coba karakterisasi konsep pada bahan ajar yang sudah terkumpul. Dari hasil uji coba karakterisasi dilakukan kategorisasi konsep pada bahan ajar ke dalam kategori mudah dan kategori sulit. Hal ini dilakukan karena dalam belajar hanya materi yang mudahlah yang akan dapat diterima oleh siswa dalam proses belajar (Anwar, 2014).

Tahap terakhir atau tahap keempat yaitu tahap reduksi didaktis. Tahap ini merupakan salah satu tahap yang cukup banyak dilakukan oleh para peneliti dan pengembang bahan ajar dalam pengembangan bahan ajar. Reduksi disini merupakan pengurangan tingkat kesulitan bahan ajar yang berdasarkan pertimbangan psikologis dan keilmuan. Dengan demikian dihasilkan bahan ajar yang baik dan dapat diterima oleh siswa sesuai dengan tingkat perkembangan psikologis serta kognitifnya.

Dalam kurikulum 2013 mata pelajaran IPA banyak konsepkonsep yang dapat dikembangkan secara terpadu sebagai bahan ajar 
IPA. Sebagai contoh pada Kompetensi Dasar (KD). $\quad 3.5$ "Memahami konsep listrik statis, muatan listrik, potensial listrik, hantaran listrik, kelistrikan pada sistem syarafdan contohnya pada hewan-hewan yang mengandung listrik" di kelas IX Sekolah Menegah Pertama (SMP) pada kurikulum pelajaran IPA Kurikulum 2013. Dalam KD ini mencakup bahasan mengenai konsep listrik pada bidang Fisika dan makhluk hidup pada bidang Biologi yang mencakup sistem saraf pada manusia, serta hewan, juga bidang Kimia yang membahas proses kimiawi di dalamnya. Konsep materi yang terdapat pada KD ini dapat diintegrasikan menjadi bahan ajar yang dikemas dalam sebuah tema "kelistrikan pada makhluk hidup" yang mencakup semua konsep diatas.

Kelistrikan pada makhluk hidup yang mencakup materi kelistrikan pada manusia dan hewan didalamnya, menjadi tema materi yang menarik untuk dijadikan bahan ajar dalam pembelajaran IPA. Konsep kelistrikan pada manusia mencakup bahasan mengenai kelistrikan di dalam tubuh khususnya yang terdapat pada sistem saraf. Pada sistem saraf terdapat penjalaran impuls melalui sinapsis (penghubung antar sel saraf) pada satu sel saraf dengan sel araf lainnya. Bedasarkan impuls saraf yang lewatinya, sinapsis dibedakan menjadi sinapsis listrik dan kimia (Priadi, 2009). Dalam bahasan materi biologi pada konsep sistem saraf akan terdapat tumpang tindih (overlaping) dengan konsep kelistrikan pada bahasan fisika serta terdapat juga tumpang tindih (overlaping)dengankonsep kimia yaitu adanya neurotransmitter sebagai impuls kimiawi, yang mana neurotransmitter ini merupakan hormon yang dihasilkan oleh neuron yang digetarkan celah sinapsis (Priadi, 2009). Selain pembahasan kelistrikan pada manusia juga terdapat pembahasan kelistrikan pada hewan.

Kelistrikan pada hewan merupakan salah satu contoh kelistrikan pada mahkluk hidup lainnya juga memiliki konsep yang 
saling tumpang tindih (overlaping) antara konsep biologi, fisika dan kimia. Terdapat beberapa jenis hewan yang juga memiliki sel-sel listrik di dalam tubuhnya seperti belut listrik. Ada pula jenis hewan yang dapat berpendar karena adanya flouroresence seperti pada ubur-ubur (Jelly fish).

Mempelajari objek hidup dan dekat dengan kita serta mempelajari fenomena yang terjadi disekitarnya secara terintegrasi menjadi sebuah cara yang menarik bagi siswa untuk belajar IPA. Namun proses pembelajaran ini tidak akan berjalan dengan baik apabila unsur-unsur penunjang pembelajarannya tidak dipersiapkan dengan baik pula, salah satunya adalah bahan ajar. Sebagai penunjang pembelajaran siswa bahan ajar selayaknya disusun secara terintegrasi sesuai dengan tuntutan kurikulum dan sesuai dengan kemampuan pedagogik serta psikologis anak sehingga bahan ajar dapat tersampaikan secara utuh dan bermakna kepada siswa. Selain itu bahan ajar yang baik dapat membantu meningkatkan intelegensi siswa salah satunya adalah berpikir secara terintegratif saat siswa dihadapkan pada permasalah atau fenomena yang terjadi disekitarnya.

Berdasarkan pemaparan di atas adanya suatu bahan ajar IPA yang terintegrasi secara konsep dan pengetahuan serta disusun berdasarkan aspek pedagogis serta psikologis peserta didik sangat dibutuhkan oleh para guru dan siswa. Hal ini salah satunya dapat difasilitasi dengan melakukan pengembangan bahan ajar dengan menggunakan metode 4STMD. Untuk memenuhi kebutuhan tersebut maka perlu dilakukan sebuah penelitian mengenai pengembangan bahan ajar IPA yang terintegrasi dengan menggunakan metode Four Step Teaching Material Development (4STMD) pada tema "Kelistrikan Pada Makhluk Hidup".

\section{B. Metode Penelitian}

Penelitian ini menggunakan metode riset dan pengembangan atau R\&D (Research and Development) yang mana dalam riset dan pengembangan dilakukan 
pengkajian dan pengembangan

secara bertahap terhadap suatu permasalahan (Sugiyono, 2012). Pada hakekatnya riset dan pengembangan merupakan suatu upaya dalam pengembangan prototipe suatu alat atau perangkat berbasis riset (Ali, 2011:393). Akker (1999, dalam Ali, 2011:393) mengungkapkan riset dan pengembangan dapat dilakukan dalam pengembangan perangkat pembelajaran, untuk kepentingan pendidikan dan pelatihan.

Dalam bidang pendidikan dan pelatihan, R\&D merupakan suatu proses pengembangan perangkat pembelajaran yang dilakukan melalui serangkaian riset yang menggunakan berbagai metode dalam suatu siklus yang melewati berbagai tahapan (Ali, 2011:395). Dalam riset dan pengembangan bahan ajar ini dilakukan beberapa tahapan pengembangan dimulai dengan pengumpulan data, pengolahan data, validasi data, uji coba dan analisis data serta pembuatan kesimpulan.

\section{Hasil Penelitian dan}

\section{Pembahasan}

Dalam penelitian ini dibahas mengenai bagaimana langkah demi langkah dalam tahapan pengembangan bahan ajar IPA terpadu pada tema kelistrikan pada makhluk hidup menggunakan metode four step teaching material development (4STMD).

Pada tahapan pertama yaitu seleksi diawali dengan melakukan pengkajian kompetensi inti (KI) dan kompetensi dasar (KD) serta penentuan tema. Hasil analisis pada KI dan KD dipilihlah tema kelistrikan pada makhluk hidup terwakili dalam KD 3.5 untuk kelas IX SMP dimana KD ini merupakan KD yang sudah terintegrasi yaitu; KD 3.5 Memahami konsep listrik statis, muatan listrik, potensial listrik, hantaran listrik, kelistrikan pada sistem sarafdan contohnya pada hewan-hewan yang mengandung listrik.Berikut adalah pemetaan konsep fisika, biologi, dan kimia dalam bahan ajar ipa pada tema kelistrikan pada makhluk hidup. 
Didaktik : Jurnal Pendidikan, ISSN : 2477-5673, E-ISSN : 2614-722X

Sekolah Tinggi Keguruan dan IImu Pendidikan Subang

Volume V Nomor 1, Juni 2019

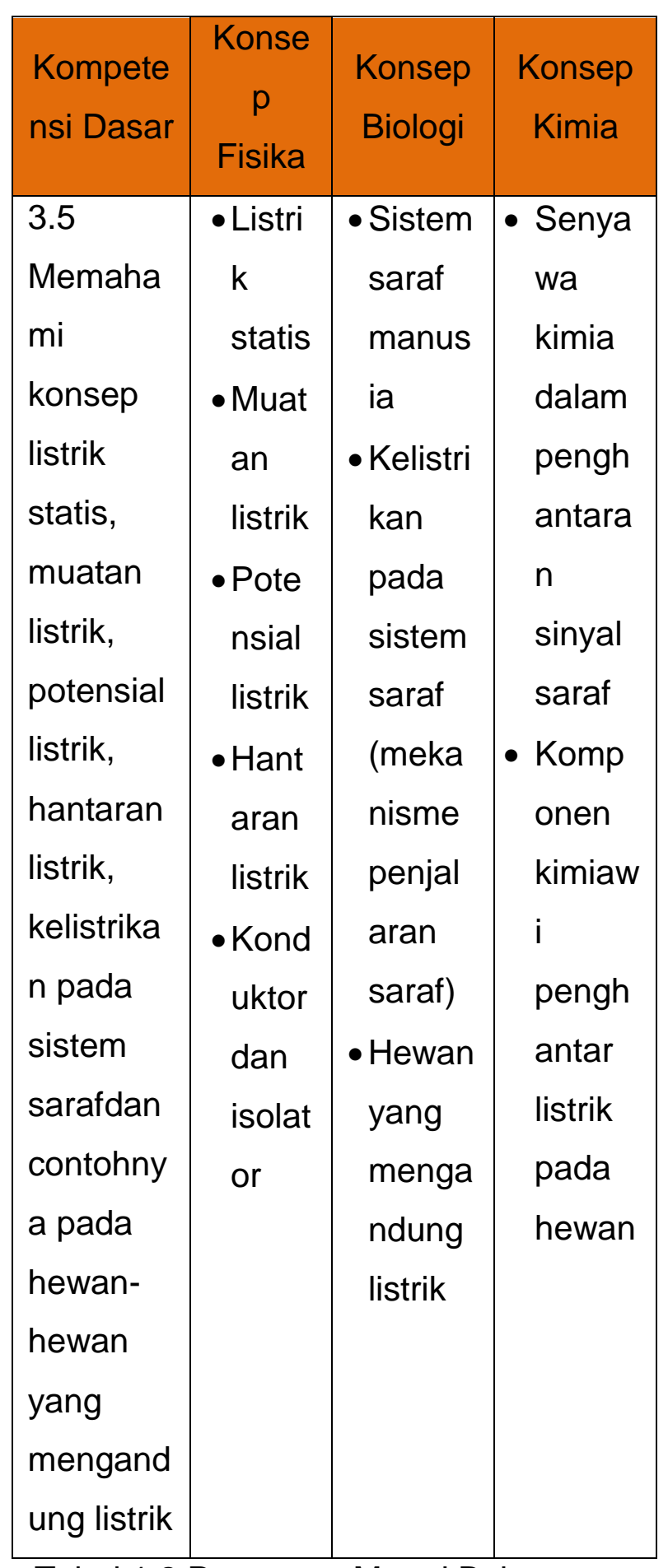

Adapun keterpaduan konsep

IPA yang mewakili fisika, biologi, dan kimia dapat dipetakan menjadi seperti pada diagram berikut:

Gambar 1.1Diagram keterpaduan konsep fisika, biologi, dan kimia

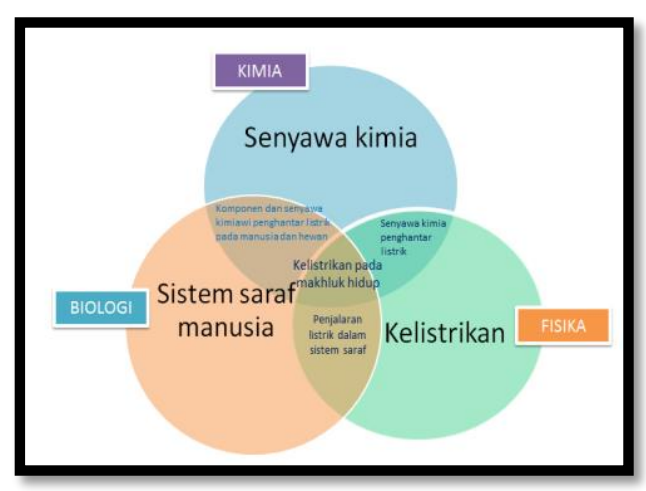

KD 3.5 kemudian dijabarkan dalam indikator sebanyak tujuh indikator. Dari ketujuh indikator ini ditentukan konsep-konsep yang sesuai dengan indikator tersebut dan ditentukan nilai-nilai yang dapat diharapkan muncul dalam diri siswa pada konsep-konsep tersebut. Indikator, konsepkonsep dan nilai tersebut kemudian divalidasi olehahli. Berikut adalah indikator yang dikembangkan dalam Ajar Kelistrikan Pada Makhluk Hidup pengembangan bahan ajar tema kelistrikan pada makhluk hidup berdasarkan hasil validasi dan perbaikan. 
Didaktik : Jurnal Pendidikan, ISSN : 2477-5673, E-ISSN : 2614-722X

Sekolah Tinggi Keguruan dan IImu Pendidikan Subang

Volume V Nomor 1, Juni 2019

Tabel 1.2. Indikator dan Konsep yang Dikembangkan dalam

Pengembangan Bahan Ajar Tema Kelistrikan Pada Makhluk Hidup

\begin{tabular}{|c|c|c|}
\hline $\begin{array}{l}\text { Kompetensi Dasar } \\
\text { (KD) }\end{array}$ & Indikator dari KD 3.5 & Konsep \\
\hline \multirow{7}{*}{$\begin{array}{l}3.5 \text { Memahami konsep } \\
\text { listrik statis, muatan } \\
\text { listrik, potensial listrik, } \\
\text { hantaran listrik, } \\
\text { kelistrikan pada sistem } \\
\text { sarafdan contohnya| } \\
\text { pada hewan-hewan } \\
\text { yang mengandung } \\
\text { listrik. }\end{array}$} & $\begin{array}{l}\text { 1. Menjelaskan peristiwa } \\
\text { listrik statis dalam } \\
\text { kehidupan sehari-hari }\end{array}$ & $\begin{array}{l}\text { - Listrik statis } \\
\text { - Peristiwa kelistrikan dalam } \\
\text { kehidupan sehari-hari }\end{array}$ \\
\hline & $\begin{array}{l}\text { 2. Mengidentifikasi } \\
\text { muatan listrik }\end{array}$ & $\begin{array}{l}\text { - Muatan positif dan Muatan negatif } \\
\text { - Muatan listrik pada benda padat } \\
\text { - Pergerakan muatan oleh ion } \\
\text { - Gaya listrik } \\
\text { - Medan Isitrik }\end{array}$ \\
\hline & $\begin{array}{l}\text { 3. Menjelaskan konsep } \\
\text { Hukum Coulomb }\end{array}$ & - Hukum Coloumb \\
\hline & $\begin{array}{l}\text { 4. Menjelaskan konsep } \\
\text { potensial listrik }\end{array}$ & - Potensial listrik \\
\hline & $\begin{array}{l}\text { 5. Menyebutkan jenis } \\
\text { konduktor dan isolator } \\
\text { dalam penghantaran } \\
\text { listrik }\end{array}$ & $\begin{array}{l}\text { - Konduktor dan isolator } \\
\text { - Jenis-jenis konduktor dan isolator }\end{array}$ \\
\hline & $\begin{array}{l}\text { 6. Menjelaskan } \\
\text { mekanisme penjalaran } \\
\text { listrik pada sistem saraf } \\
\text { manusia }\end{array}$ & $\begin{array}{l}\text { - Mekanisme penjalaran sinyal listrik } \\
\text { pada saraf manusia } \\
\text { - Senyawa kimia Neurotransmiter }\end{array}$ \\
\hline & $\begin{array}{l}\text { 7. Mengidentifikasi } \\
\text { kelistrikan pada hewan }\end{array}$ & - Kelistrikan pada hewan \\
\hline
\end{tabular}




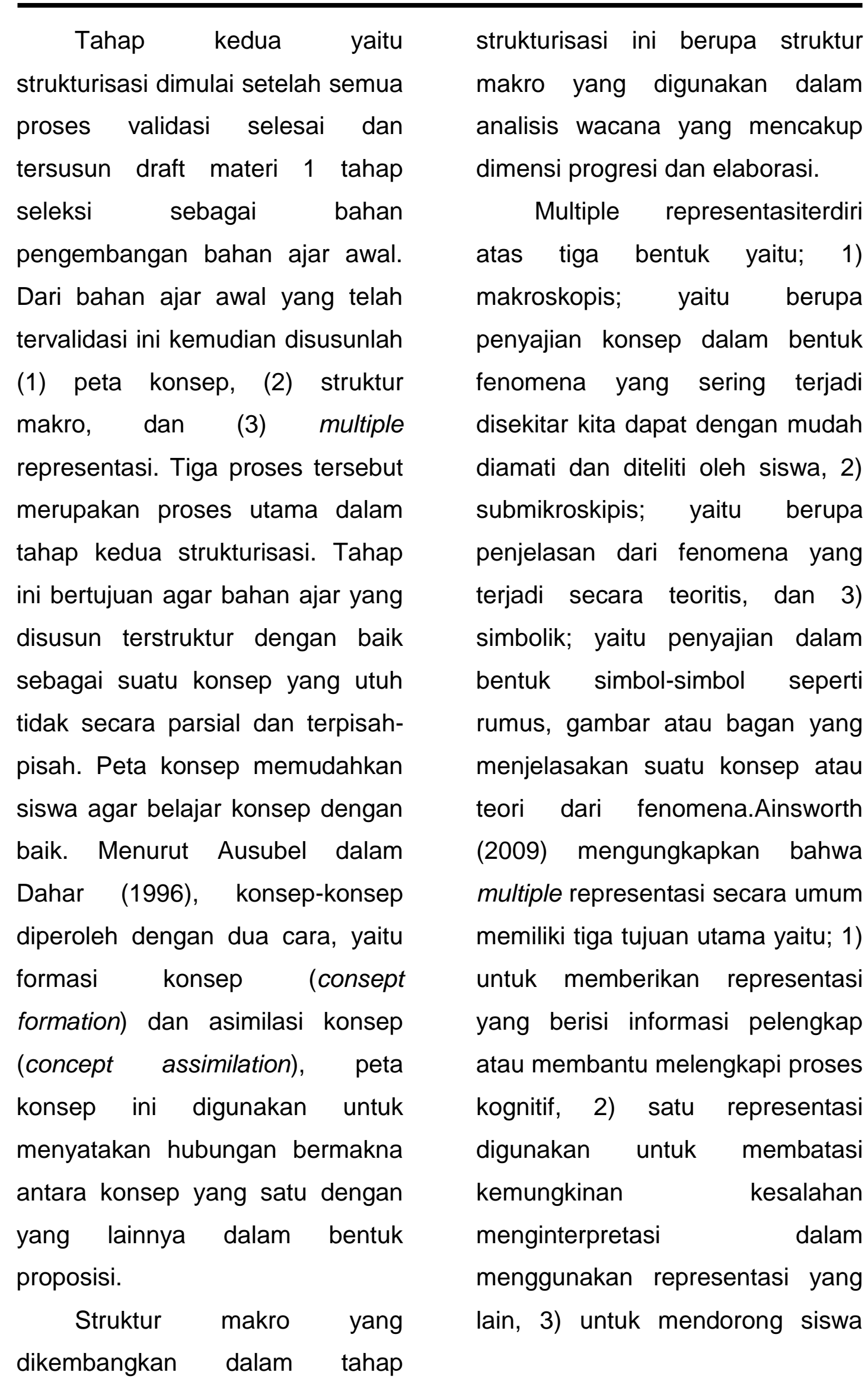


Didaktik : Jurnal Pendidikan, ISSN : 2477-5673, E-ISSN : 2614-722X

Sekolah Tinggi Keguruan dan IImu Pendidikan Subang

Volume V Nomor 1, Juni 2019

membangun pemahaman terhadap

situasi secara mendalam.

Contoh multiple representasi pada konsep listrik statis dimulai dengan representasi makroskopis yang menyajikan fenomena berdirinya rambut saat didekatkan dengan balon yang telah digosokgosokkan dengan kain sutra, pada representasi submikroskopis dijelaskan bahwa terdapat perpindahan muatan dengan cara menggosok-gosokkan dan secara representasi simbolis digambarkan posisi muatan listrik statis yang bekerja pada benda. Setelah semua tahapan strukturisasi dilakukan pengumpulan draft materi kembali yaitu draft materi 2 yang telah dilengkapi dengan peta konsep, struktur makro dan multiple representasi.

Tahapan yang ketiga yaitu karakterisasi, pada tahapan ini dilakukan uji lapangan yaitu uji keterpahaman konsep-konsep yang terdapat pada bahan ajar yang disusun kepada sejumlah siswa. Uji keterpahaman ini untuk mengetahui karakteristik sulit atau mudah terhadap bahan ajar yang dikembangkan.

Instrumen keterpahaman ini berupa tes keterbacaan ide pokok, tes rumpang mengenai konsep, mencocokkan istilah pada konsep, dan penafsiran gambar. Instrumen ini disajikan dalam 16 teks dan 32 butir soal pilihan ganda yang mewakili setiap indikator. Instrumen juga disertai dengan pilihan pernyataan tingkat sulit atau mudah yang harus diisi oleh siswa.

Hasil uji keterpahaman menunjukkan terdapat lima teks pada pada bahan ajar yang dikembangkan yang memiliki konsep sulit sehingga ke lima teks ini dilakukan analisis konsep sulit menjadi abstrak, kompleks, atau rumit. Adapun ke lima teks ini meliputi materi tentang muatan listri, kelistrikan pada sistem saraf manusia, dan kelitrikan pada hewan. Hasil analisis konsep sulit ini dijadikan sebagai bahan kis-kisi untuk tahap reduksi didaktis. Prinsip-prinsip didaktik yang harus dijadikan sebagai pedoman oleh setiap guru dalam menyampaikan materi yaitu dari simpel menuju kepada yang kompleks, dari yang dekat ke yang jauh, dari yang 
mudah ke yang sukar, dari yang konkret ke yang abstrak dan sebagainya, sebagaimana dikatakan oleh Commenius (15921670) dalam Anwar (2014) tentang tulisannya tentang prinsip "mudah dalam pembelajaran" sebagai salah satu prinsip didaktik.

Reduksi diartikan sebagai pengurangan tingkat kesulitan bahan ajar, sebab pada proses ini bahan ajar direduksi secara didaktis, dengan pertimbangan aspek psikologis dan keilmuan, agar bahan ajar yang telah mengalami reduksi ini dapat dipahami oleh para pembelajar (siswa) dengan mudah. Terdapat beberapa cara untuk melakukan reduksi didaktis terhadap suatu bahan ajar diantaranya yaitu; 1) Kembali kepada tahapan kualitatif, suatu eksplanasi pedagogik ataupun ilmiah jika dipresentasikan dalam bentuk data kuantitatif (angka-angka) hampir selalu dalam keadaan yang lebih kompleks dan sulit, 2) Pengabaian, hasil berbagai temuan ilmiah, baik yang dipresentasikan dalam eksplanasi ilmiah maupun eksplanasi pedagogik yang terdapat pada buku, biasanya telah mengalami berbagai pengabaian, 3) Penggunaan penjelasan berupa gambar, simbol, sketsa, dan percobaan hal-hal ini dilakukan untuk memperjelas bahan ajar yang tidak dapat dimengerti secara tulisan,4) Penggunaan Analogi, penggunaan analogi dapat digunakan untuk menjelaskan konsep-konsep yang astrak dan sulit dalam konsep IPA, 5) Penggunaan tingkat perkembangan sejarah ilmu pengetahuan berkembang mulai dari konsep yang sederhana hingga pengetahuan yang saat ini dipandang rumit. Penggunaan konsep-konsep yang sederhana (ilmu pengetahuan lama) akan membantu siswa dalam memahami konsep-konsep yang saat ini disebut modern, 6) Generalisasi, berbagai hasil pemikiran dan penelitian seluruhnya ditulis dalam bentuk kesimpulan (proses induksi) yang menggambarkan seluruh hasil pemikiran dan penelitian tersebut, 7) Partikulisasi, suatu konsep yang kompleks dapat dibuat sederhana dengan partikulisasi. Partikulisasi 
adalah pemilahan informasi dari konsep yang memiliki informasi banyak (kompleks) menjadi bagian-bagiannya yang lebih sederhana, 8) Pengabaian perbedaan pernyataan konsep, cara reduksi ini diperlukan karena banyak istilah-istilah ilmiah yang pada kehidupan sehari-hari banyak digunakan.

Adapun pada bahan ajar yang dikembangkan dilakukan proses reduksi didaktis dapat dilihat pada Tabel 1.3 sebagai berikut:

\begin{tabular}{|c|c|c|l|}
\hline $\begin{array}{c}\text { No } \\
\text { Indikator }\end{array}$ & $\begin{array}{c}\text { No } \\
\text { Teks }\end{array}$ & $\begin{array}{c}\text { Jenis } \\
\text { Kategori } \\
\text { Sulit }\end{array}$ & \multicolumn{1}{|c|}{ Tindakan Reduksi } \\
\hline 2 & 4 & Rumit & Generalisasi \\
\hline \multirow{2}{*}{6} & 12 & Abstrak & Penggunaan penjelasan dengan gambar \\
\cline { 2 - 4 } & 13 & Kompleks & Partikulasrisasi \\
\cline { 2 - 4 } & 14 & Rumit & Generalisasi \\
\hline 7 & 16 & Abstrak & Penggunaan penjelasan dengan gambar \\
\hline
\end{tabular}

Sebagai upaya untuk mengetahui efektifitas bahan ajar yang dikembangkan dilakukan uji kelayakan bahan ajar terhadap kemampuan berpikir integrasi pengetahuan siswa dengan melibatkan dua kelas siswa kelas VIII Sekolah Menengah Pertama (SMP) yang belum pernah mempelajari materi kelistrikan pada makhluk hidup sebelumya. Satu kelas siswa kelas VIII dijadikan sebagai kelas eksperimen yang diberikan handbook bahan ajar yang dikembangkan dengna metode 4STMD dan satu kelas VIII sebagai kelas kontrol diberikan bahan ajar yang disusun oleh pusat perbukuan yaitu Buku Sekolah Elektronik (BSE) dengan materi yang sama. Kedua kelas tersebut diberikan waktu untuk mempelajari bahan ajar yang diberikan selama dua hari kemudian diberikan sejumlah butir soal untuk menjaring kemampuan berpikir integrasi pengetahuan siswa. Adapun level kemampuan 
Didaktik : Jurnal Pendidikan, ISSN : 2477-5673, E-ISSN : 2614-722X

Sekolah Tinggi Keguruan dan IImu Pendidikan Subang Volume V Nomor 1, Juni 2019

berpikir integrasi pengetahuaan mengacu kepada level berpikir integrasi pengetahuan yang dikembangkan oleh Lee dan Liu
(2009) dan telah disesuaikan berdasarkan kebutuhan penelitian dapat dilihat pada tabel $1.4 \mathrm{di}$ bawah ini:

\begin{tabular}{|c|c|c|}
\hline $\begin{array}{c}\text { Tingkat } \\
\text { Integrasi } \\
\text { pengetahuan }\end{array}$ & Skor & Karakteristik jawaban siswa \\
\hline Complex-link & 5 & $\begin{array}{l}\text { Siswa memunculkan dan menghubungkan } \\
\text { tiga atau lebih ide yang sesuai dan relevan } \\
\text { dengan konteks ilmu pengetahuan yang } \\
\text { diberikan }\end{array}$ \\
\hline Full-link & 4 & $\begin{array}{l}\text { Siswa memunculkan dan menghubungkan } \\
\text { dua ide yang sesuai dan relevan dalam } \\
\text { konteks ilmu pengetahuan yang diberikan }\end{array}$ \\
\hline Partial-link & 3 & $\begin{array}{l}\text { Siswa memunculkan ide yang sesuai dan } \\
\text { relevan dengan konteks ilmu pengetahuan } \\
\text { yang diberikan }\end{array}$ \\
\hline No-link & 2 & $\begin{array}{l}\text { Siswa memunculkan ide yang tidak sesuai } \\
\text { atau membuat hubungan yang tidak sesuai } \\
\text { dengan konteks ilmu pengetahuan yang } \\
\text { diberikan }\end{array}$ \\
\hline Irrelevant & 1 & $\begin{array}{l}\text { Siswa tidak memunculkan ide yang sesuai } \\
\text { dengan dengan konteks ilmu pengetahuan } \\
\text { yang diberikan }\end{array}$ \\
\hline $\begin{array}{l}\text { No } \\
\text { information }\end{array}$ & 0 & Siswa tidak memberikan informasi apapun \\
\hline
\end{tabular}

Hasil dari kedua kelas menunjukkan bahwa rata-rata kemampuan berpikir integrasi pengetahuan siswa berada pada level berpikir partial-link. Namun secara individu pada kelas eksperimen siswa mencapai level full-link dan complex-link 
sedangkan pada kelas kontrol hanya pada level full-link.

\section{Kesimpulan}

Berdasarkan hasil analisis dan pembahasan dalam penelitian ini diketahui

1. Bahan ajar IPA terpadu tema kelistrikan pada makhluk hidup dapat dikembangkan dengan baik menggunakan metode Four Step Teaching Material Development (4STMD).

2. Setiap tahapan pada metode 4STMD memiliki peranan penting untuk menghasilkan bahan ajar yang memiliki kualitas yang baik sesuai dengan kemampuan kognitif dan psikologis siswa yang terlihat pada hasil uji kelayakan bahan ajar oleh ahli dan berdasarkan pada tanggapan siswa.

3. Tahap seleksi dalam pengembangan bahan ajar ini menjadikan adanya keragaman sumber bahan ajar yang dikembangkan karena banyaknya sumber yang digunakan.
4. Peta konsep, struktur makro dan multiple representasi pada tahap Strukturisasi menjadikan bahan ajar yang dikembangkan lebih mudah dipahami dengan konsep yang disajikan secara terstruktur.

5. Tahap karakterisasi penting dilakukan untuk mengetahui konsep-konsep pada bahan ajar yang dikembangkan sebelum bahan ajar digunakan oleh siswa. Hasil analisis konsep sulit pada tahap karakterisasi menjadi landasan untuk perbaikan pada tahap reduksi didaktis.

6. Dengan melakukan tindakan reduksi didaktis sesuai dengan tingkat kesulitan bahan ajar menjadikan bahan ajar ini lebih baik dan lebih mudah dipahami oleh siswa.

7. Hasil uji efektifitas bahan ajar yang dikembangkan terhadap kemampuan berpikir integrasi pengetahuan siswa dihasilkan skor rata-rata yang lebih tinggi pada kelas eksperimen dibandingkan skor rata-rata pada kelas kontrol yaitu 37,12 pada kelas ekperimen dan 34 
Didaktik : Jurnal Pendidikan, ISSN : 2477-5673, E-ISSN : 2614-722X

Sekolah Tinggi Keguruan dan IImu Pendidikan Subang

Volume V Nomor 1, Juni 2019

pada kelas kontrol. Secara

keseluruhan kedua kelas

memiliki level kemampuan

integrasi pengetahuan yang

sama yaitu pada level Partial-

link, namun secara individu

pada kelas eksperimen terdapat

siswa yang mencapai level Fulllink dan Complex-link sedangkan pada kelas kontrol hanya pada level Full-link.

\section{DAFTAR PUSTAKA}

Ainsworth, S. (1999). The Function

of Multiple Representation.

Computers and Education. 33, 131-152.

Anwar, S. (2013). Pengelohan Bahan Ajar. Hand Out Perkuliahan. Tidak

Diterbitkan. Bandung.

Sekolah Pasca Sarjana UPI.

Dahar, R. (1996). Teori-teori Belajar. Jakarta: Erlangga Forgarty, R. (1991). The Mindful School: How to Integrate the
Curricula. United State of America: IRI/Skylight

Publishing, Inc.

Lee \& Liu. (2009). Assesing Learning Progression of Energy Concept Accross Middle School Grades: The Knowledge Integration Perspective Article In Wiley Interscience. Published online 17 November 2009. DOI: 10.1002/sce.20382.

Permendikbud. (2013).

Permendikbud No 65 Th 2013 Tentang Standar Proses Pendidikan Dasar dan Menengah. Kemendikbud.

Suparno, P. (2001). Teori Perkembangan Kognitif Jean Piaget. Yogyakarta: Kanisius. Sagala, S. (2009). Konsep dan Makna Pembelajaran.

Bandung : Alfabeta. 